\title{
IRRIGATION RESPONSE OF POTATO (Solanum tuberosum L.) VAR. R12 DIACOL CAPIRO
}

\section{RESPUESTA DE LA PAPA (Solanum tuberosum L.) VARIEDAD R12-DIACOL CAPIRO A LA APLICACION DE RIEGO}

\author{
Fernando Javier Peña Baracaldo ${ }^{1}$, Ingeborg Zenner de Polanía ${ }^{2}$
}

${ }^{1}$ Ing. Agr. M.Sc., Docente Investigador, Facultad Ingenierías, Programa Ingeniería Agronómica. Universidad de Ciencias Aplicadas y Ambientales U.D.C.A. Calle 222 No. 55-37, Bogotá, D.C., e-mail: fepena@udca.edu.co; ${ }^{2}$ Ing. Agr. Ph.D. Universidad de Ciencias Aplicadas y Ambientales U.D.C.A. Calle 222 No. 55-37, Bogotá, D.C., e-mail: izenner@udca.edu.co

Rev. U.D.C.A Act. \& Div. Cient. 18(2): 385-392, Julio-Diciembre, 2015

\section{SUMMARY}

Irrigation is one of the agronomic practices seldom employed by potato growers, either because of water unavailability or lack of knowledge of the benefits of the appropriate water use. In order to demonstrate this benefit, in a cycle of five months, regarding of a commercial crop located in Tenjo (Cundinamarca), we evaluate the response of the potato variety Diacol Capiro R-12 to three treatments, fertigation (T1), drip irrigation (T2), and the comparison with a conventional check without irrigation (T3), distributed under a completely randomized design. The influence of the treatments on the fresh and dry weight of leaves, stems and tubers was estimated. Throughout the assessment, the irrigation and fertigation treatments were superior to conventional one, showing statistically significant differences at harvest time, where treatment $\mathrm{T} 1$ showed an increase in yield of $72 \%$ and treatment T2 of $18 \%$, compared with the control. Based on the results, fertigation can be considered as an option for farmers to increase their potato profitability and market competitiveness, since the impact generated by price fluctuations of the product can be reduced, obtaining higher and more constant yield per area unit, regardless of weather conditions during the crop cycle.

Key words: Irrigation systems, tuber production, yield, rainfall.

\section{RESUMEN}

El riego, en el cultivo de papa, es una de las prácticas culturales menos empleadas por los cultivadores de este tubérculo, ya sea por no disponibilidad de agua o por ausencia de conocimiento del beneficio del uso adecuado del agua. Para demostrar este beneficio, en un ciclo de cinco meses de un cultivo comercial, localizado en Tenjo (Cundinamarca), se evaluó la respuesta de la papa, variedad R-12 Diacol Capiro, a tres tratamientos, fertirriego (T1), riego por goteo (T2), comparado con un testigo convencional sin riego (T3), distribuidos bajo un diseño completamente aleatorizado. Se estimó la influencia de los tratamientos sobre la longitud de los tallos, el peso fresco y seco en hojas y peso freso de tubérculos. A lo largo de la evaluación realizada, los tratamientos riego y fertirriego fueron superiores al testigo convencional, mostrando diferencias estadísticamente significativas Tukey $(p<0,05)$, en el momento de la cosecha, donde el tratamiento $\mathrm{T} 1$ presentó un aumento en rendimiento del $72 \%$ y, el tratamiento T2, del 18\%, con relación al testigo. Con los resultados obtenidos, se percibe al fertirriego como una opción para que los agricultores puedan aumentar su rentabilidad y su competitividad en el mercado, ya que pueden disminuir el impacto que generan las fluctuaciones en los precios de venta del producto, al tener rendimientos por unidad de área superiores y constantes, independientemente de las condiciones climáticas que se tengan durante el ciclo del cultivo.

Palabras clave: Sistemas de riego, producción tubérculos, rendimiento, lluvias.

\section{INTRODUCTION}

After the maize, wheat and rice, potato is worldwide the fourth most consumed food. FAO reports a global cultivated area of 19'463.041 ha with a production of 368'096.362t for 2013; from these hectares Colombia has planted 114.715ha and harvested 2'129.319t (FAOSTAT, 2014), which represents, on average a $32 \%$ of the production of its annual crops. The crop is grown throughout the year in nearly 133.865ha estimated for 2012, providing around 90,000 jobs, which 
according to the "Colombian National Potato Board" in 2009 generated about 77,369 direct and 232,108 indirect occupations (FEDEPAPA, 2014).

Because of the diversity of producers and the different technologies used during the production process, yield per hectare is variable and relatively low, being on average18.4t/ ha, although DANE records shows producers with yields higher than 40t/ha exist (DANE, 2013), this yields are not very far from the one obtained in New Zealand, the country with the highest yields with a national average of $44.71 \mathrm{t} / \mathrm{ha}$ (FAOSTAT, 2014). As reported by Sermet et al. (2005) the most important factor, which when not managed properly to achieve these levels of productivity, is the low availability of water during the growing season.

The lack of irrigation water has negative effects on every phenological stage of the crop, the initiation of tuber formation and the tuber filling are the most important stages influenced by lack of adequate soil humidity. It also influences the quantity and quality of tubers, since drought generates elongated or deformed tubers (Ekanayake, 1994). Another important aspect of the lack of adequate soil moisture refers to the attack of insects, specifically the Guatemaltecan potato tuber moth, Tecia solanivora Povolny (Lepidoptera: Gelechiidae). A soil with a moisture content at or higher than field capacity, prevents the existence of cracks around the stem base and avoids, or at least hinders, the moth oviposition and the subsequent access of the first instar larvae to the tubers (Torres, 1997).

In 1990, Haverkort et al. showed that irrigation is vital in the potato production, particularly when there is no nutritional or plant population limits. An adequate water supply is critical from the tuberization initiation until the plant reaches physiological maturity in order to obtain high yields of excellent quality (Haverkort et al. 1990; Sermet et al. 2005; Tourneux et al. 2003b). Furthermore, an adequate supplies of water before tuber formation increases the number and the size of tubers per plant (Aguiar Netto et al. 2000) and, consequently, increases the yield (Pacheco Saguí \& Pérez Correa, 2010).

Research carried out in Venezuela demonstrated the positive influence of irrigation on decreasing the damage of $T$. solanivora. Ramos de Solózano et al. (1995) determined the water requirements of the crop and its effect on the incidence of the insects, evaluating water sheets between 500 and $2,500 \mathrm{~mm}$; the authors concluded that the increase of the water sheet from 500 to $2,500 \mathrm{~mm}$ decreased the percentage of affected tubers from 66.67 to $25.88 \%$. Sprinkler irrigation, at a frequency of five days, maintained a proper soil moisture, and decreased the damage caused by the larvae of the insect pest to tubers of the variety "Granola", showing a tuber infestation of only 6.64\% at harvest time (Fernández, 1996).
Sun et al. (2014) explain that to obtain high yields soil water availability for cultivation must be maintained at a level of $70 \%$ throughout the developmental cycle. According to Jeréz \& Simpfendöfer (2000) crop water requirements vary between 400 and $600 \mathrm{~mm}$, but all rain less than $10 \mathrm{~mm}$ is ineffective or does not contribute to the crop, as it is retained by the foliage and is evaporated. According to Solano et al. (2003) higher than $500 \mathrm{~mm}$ levels are considered optimal. In this connection Ferreira \& Goncalves (2007) show that for obtaining good yields and in relation to the climatic conditions on the area, the crop needs between 460 and $480 \mathrm{~mm}$ while Aguilar et al. (2006) report needs near 455 $\mathrm{mm}$ during the growing season.

The potato plant is sensitive to water stress and water availability in the soil cannot be less than $30 \%$ to achieve optimum yields (Darwish et al. 2006; Tourneux et al. 2003a). In the crop, a high availability of assimilates promotes the growth of roots, of stolons, the leaves and branches (Tourneux et al. 2003a; b). During the foliage expansion phase, water stress reduces photosynthetic efficiency, growth of foliage and favors partitioning of assimilates to the growth of the tubers; thus, especially when the tuber formation has already initiated (Haverkort et al. 1990; Sermet et al. 2005; Darwish et al. 2006). Another effect of water stress is the reduction of foliage growth for the partition of assimilates to the tubers, which determines a decrease of the crop cycle (Geremew et al. 2007).

Being the potato crop such an important line within the Colombian economy, production processes have to be improved, being one of the aspects to which little importance is played is, precisely the real water management. With this in mind, drip irrigation or fertigation could be a great alternative, since it allows a more efficient water management, as well as a better nutritional management of the plant (Bosnjak \& Pejik, 1997).

Therefore, it is considered, that irrigation is an alternative to increase yields, to improve water use and to reduce the dependence on weather conditions; that's why the objective of this research was to evaluate the effect of two irrigation systems on the yield of the potato variety Diacol Capiro R-12.

\section{MATERIALS AND METHODS}

The research was carried out in a commercial plot located in the township of Poveda 2 Tenjo, Cundinamarca, Colombia; latitude $4^{\circ} 52^{\prime} 42.43^{\prime \prime} \mathrm{N}$ and longitude $74^{\circ} 5^{\prime} 50.18^{\prime \prime} \mathrm{W}$ in a loam soil with coarse texture.

The electrical conductivity $(\mathrm{EC})$ and $\mathrm{pH}$ of the irrigation water and soil were measured, being the water EC Water $0.71 \mathrm{~ms} /$ $\mathrm{cm}$ (conductivity variable), of intermediate salt levels suitable 
for irrigation, such as $\mathrm{Ca}$, and possibly undesirable as $\mathrm{Cl}$ and Na; with these the crops productivity is not affected. Water $\mathrm{pH}$ was 6.30, which is within the ranges to be used in fertigation. Soil EC ratio 2:1 was $0.63 \mathrm{~ms} / \mathrm{cm}$, which indicates the adequate fertility, the low-toxic salts, with an optimum nutrient reserve, and suitable cation exchange capacity that provides a good potential for achieving high returns if proper management of fertigation is performed.

The seed material used was the potato variety Diacol Capiro, known as R-12, a medium late variety (165 days approx.), intended for industrial processing. Under optimal growing conditions, yields may be higher than 40t/ha (Ñústez et al. 2009).

A drip irrigation system consisting of 16 modules, each one with 16 lines of $80 \mathrm{~m}$ length, and a discharge of 30 gallons per minute $^{-1}$ (GLM) per module was installed. One hour weekly watering during the crop cycle was performed; thus providing irrigation of $7.5 \mathrm{~mm}$ per hectare during each irrigation.

The soil was prepared with one pass of a vibratory chisel and two rake passes; planting was done with a potato planter (Watanabe PAI-290) driven by a tractor; the distance between rows were $1 \mathrm{~m}$ and $30 \mathrm{~cm}$ between plants, obtaining a density of 33,333 plants/ha. The initial fertilization took place at planting time at the rate of $750 \mathrm{k}^{\mathrm{h}-1}$, with a fertilizer grade 13-26-6-5-6. Agronomic practices were realized according to the routines done by the producer.

Fertilization was carried out according to the soil analysis and the bases were balanced in the ratio 1:3:1, according to the methodology established in the "Manual de Monómeros Colombo Venezolanos" according to the extraction of the crop for the Cundi-Boyaca plateau, giving to Santos et al. (2010). For treatment number 1 the fertilization was $30 \%$ at planting, the remaining $70 \%$ was applied weekly by the fertigation system, splitted rendering to the crops phenology and using the methodology recommended by Cadahía (1996). Fertilizers used were of high solubility and concentration of the element in order to reduce problems of soil salinity. For treatments for 2 and 3 preplant fertilization was 30\% and the remaining $70 \%$ at the hoeing time.

A completely randomized experimental design was used, composed of three treatments with three replicates each: fertigation (T1), drip irrigation (T2) and the commercial control without irrigation (T3), for a total of nine experimental units, consisting each of three rows $80 \mathrm{~m}$ long per treatment, with an area of $240 \mathrm{~m}^{2}$ per treatment. The effect of these treatments on the variables, stem length and dry weight, fresh and dry leaf weight and tuber fresh weight of ten plants per row was measured. It was also proposed to evaluate, when taking the tuber fresh weight, to evaluate the percentage of damage of $T$. solanovora. For all the data analysis of variance and multiple comparison test of Tukey $(p<0.05)$ was performed.

\section{RESULTS AND DISCUSSION}

Stem length: The influence of either irrigation type on this parameter is shown in figure 1; from week 11 after planting (WAP), treatment T3 showed a shorter stem length than both $\mathrm{T} 1$ and T2. However, in the last evaluation T1 reveals the lowest stem length, $114.00 \mathrm{~cm}$, while treatment T2, averaged $151.11 \mathrm{~cm}$. Within the samples taken at the WAP 7, 9, 19 and 21 , none of the treatments had an influence on this parameter. In week 11, treatment T3 showed an average of $28.91 \mathrm{~cm}$, is realized that this is statistically lower than treatments $\mathrm{T} 1$ and T2, which reached a higher average, 54.05 and $57.84 \mathrm{~cm}$, respectively. At week 13 WAP, T1 and T2 are within the same statistical grouping, larger than the T3. Afterwards, at week 15, treatment T1 displayed a greater length, while T2 and T3, with the lowest average assessment, are grouped with no significant differences between them. Finally, at week 17 WAP, the two irrigation systems, treatments T1 and T2, reached the highest data, statistically equally grouped with the same height, while in the control without irrigation, stems only reached an average height of $90 \mathrm{~cm}$, statistically different from the other two treatments.

Definitely, the irrigated potato plants presented along the crop cycle higher values in stem length. This finding agrees with the statement made by Motalebifarda et al. (2013), who found that lower levels of soil moisture the crops evapotranspiration rates is shortened; this triggers a decrease in the absorption and transport of nutrients, adversely affecting the growth of stems and of the plant.

Stem dry weight: Results of the evaluation of this parameter are provided in figure 2. It is noted that T2 and T3 have a similar behavior throughout the study, whereas treatment T1 presented higher values at weeks 13, 15 and 17; however, at the end it behaves similar to treatment T3.

At week 13 after planting, treatment T1 reached the highest value with a dry weight of $153 \mathrm{~g}$, different as the one reported by Nústez et al. (2009), who mentioned that the maximum dry matter accumulation in this organ was $105,87 \mathrm{~g}$ per plant at 12 weeks after emergence. This difference is attributed to the effect of fertigation on the stem development and the accumulation of nutrients and fotoasimilates with in them. Also, at this week, treatment T1 showed significant differences with treatment T2, exhibiting an increase of $183 \%$ with respect to $\mathrm{T} 2$, which with $54 \mathrm{~g}$ dry weight exhibits the lowest value. In regard to T3 an increase of $82 \%$, with $84 \mathrm{~g}$, similar to the other treatment was obtained. 


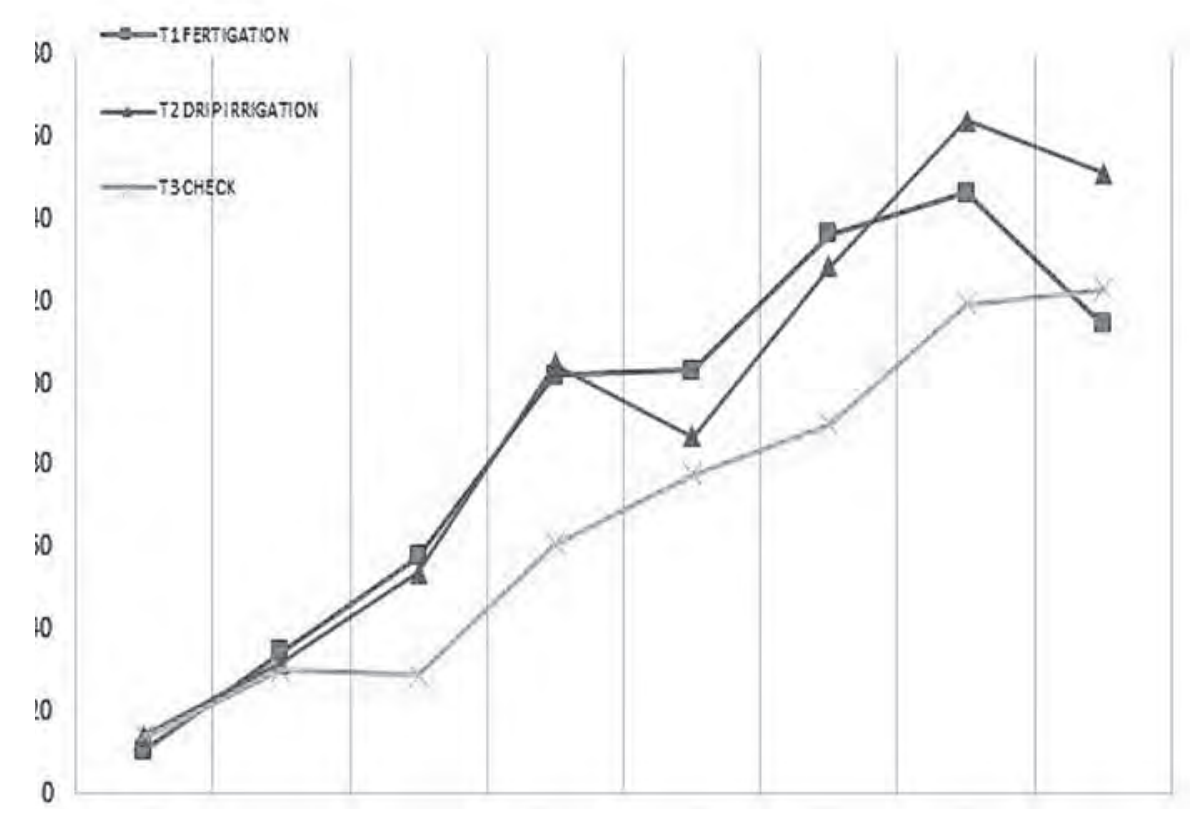

Figure 1. Mean plant stem length during the potato phenological development with and without irrigation.

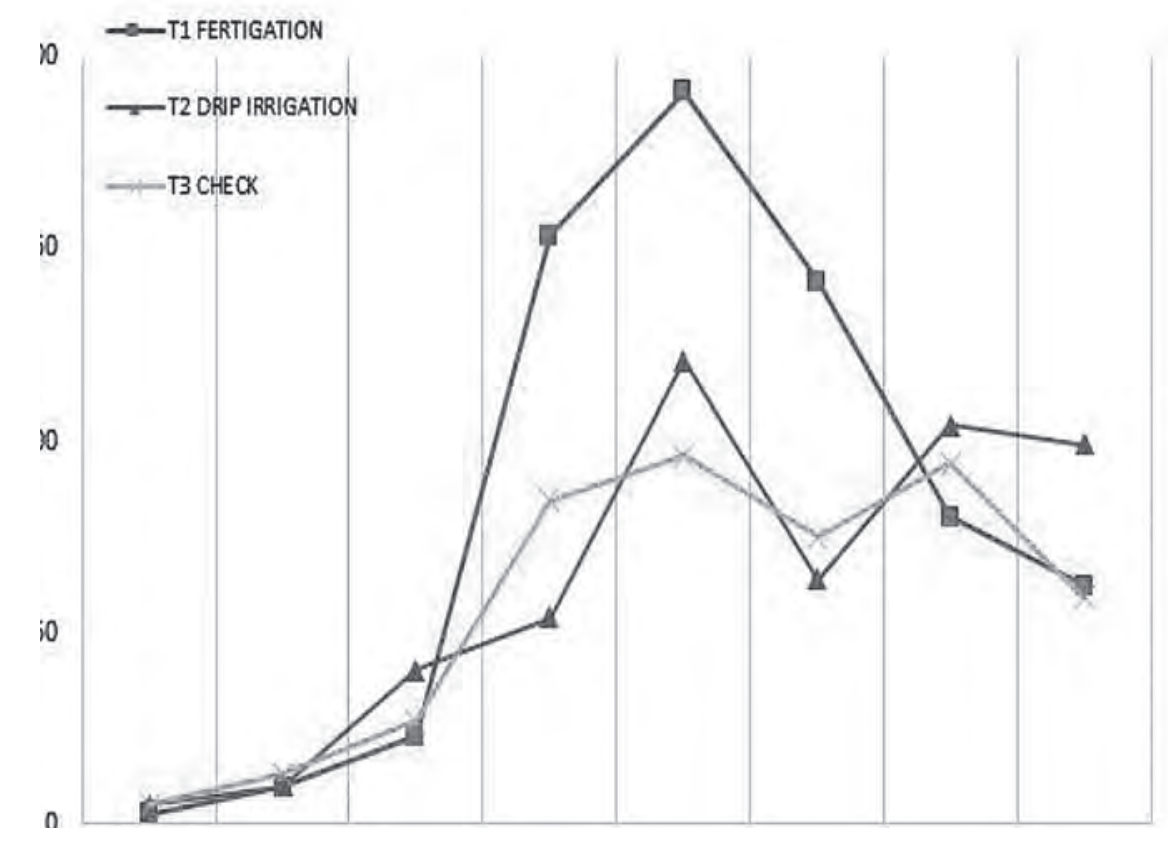

Figure 2. Stem dry weight evolution of R-12 potato with and without irrigation.

Fresh and dry weight of leaves: In table 1 the average of these two parameters are reported, showing that the fresh weight of the leaves showed a trend of continuous increase, up to week 15; where treatments T1 and T2 reached the highest fresh leaf weight, which matches with the data obtained by Rodríguez (2010), who reported the highest dry matter accumulation in this organ in the $14^{\text {th }}$ week after planting. 
At WAP 15, the fresh weight obtained of treatment T2 was $107 \%$ higher than that for T3; while T1 was $188 \%$ higher than T3 and 39\% higher than T2. Moreover, in this sample, significant differences among treatments were presented. From this week on, the trend of the values obtained is in the decrease, and at week 21 WAP statistically significant differences between T1 and T3 and T2 are present, having the latter one a considerably higher value. Analysis of variance showed statistically significant differences only for samples taken at weeks 15 and 21.

Table 1. Mean fresh and dry weight of R-12 of potato leaves.

\begin{tabular}{|c|c|c|c|c|c|c|}
\hline $\begin{array}{l}\text { Weeks after } \\
\text { planting }\end{array}$ & $\begin{array}{c}\text { Fresh } \\
\text { T1 }\end{array}$ & $\begin{array}{c}\text { Weight } \\
\text { T2 }\end{array}$ & $\begin{array}{c}\mathbf{g} \\
\text { T3 }\end{array}$ & $\begin{array}{c}\text { Dry } \\
\text { T1 }\end{array}$ & $\begin{array}{c}\text { Weight } \\
\text { T2 }\end{array}$ & $\begin{array}{c}\mathbf{g} \\
\text { T3 }\end{array}$ \\
\hline 7 & 32,28 & 63,39 & 51,70 & 4,04 & 8,04 & 6,89 \\
\hline 9 & 235,55 & 176,26 & 170,61 & 23,46 & 11,09 & 13,35 \\
\hline 11 & 519,18 & 495,87 & 112,72 & 56,81 & 25,13 & 34,68 \\
\hline 13 & 723,39 & 508,00 & 591,51 & 120,76 & 68,79 & 40,15 \\
\hline 15 & $1002,38^{a^{a}}$ & $718,33^{\text {b }}$ & $346,90^{\text {c }}$ & $175,56^{\text {a }}$ & $77,79^{\text {b }}$ & $37,02^{\text {c }}$ \\
\hline 17 & 546,67 & 578,33 & 326,90 & 79,80 & 27,81 & 33,83 \\
\hline 19 & 388,33 & 400,00 & 391,67 & 44,06 & 42,07 & 103,12 \\
\hline 21 & $73,33^{\text {a }}$ & $220,00^{\text {b }}$ & $63,33^{\text {a }}$ & 43,27 & 53,16 & 39,39 \\
\hline
\end{tabular}

* Tukey $(\mathrm{p}<0,05)$

As shown in table 1, treatments $\mathrm{T} 1$ and $\mathrm{T} 2$ presented throughout the crop cycle higher leaf fresh weight. This result agrees with the statement made by Tabares et al. (2009) who obtained that leaf area for crops with complete irrigation is superior as those who have had a deficit during its development.

Reaching maturity and harvest, plants start to lose leaves and the final tuber fill depends on the remaining photoasimilates that are contained in stems and roots; soil should have a certain moisture degree to prevent cracks that serve as entrance for diseases and pests of the crop (Haverkort et al. 1990).

In the same table 1 it appears that the dry weight of leaves for the evaluated treatments reveals an equivalent tendency equivalent to increase or decrease observed with the behavior of the fresh weight. An increase is detected at the interval between weeks 13 and 15 after planting, and then a downward trend is reflected. The dry matter increase at week 15 of plants of the treatments T1 and T2 can be explained by the application of irrigation and fertigation, respectively, since water increases soil availability of nutritional and then facilitates translocation to the leaves (Geremew et al. 2007). Leaf dry weight found in this week differ little from the data collected by Nústez et al. (2006) in a study on the dry matter accumulation and distribution in Diacol Capiro, study in which the greatest accumulation of dry matter fluctuated around $11.5 \mathrm{~g}$ per plant.
Again, it is made evident that throughout the crop cycle the treatments, which received irrigation, had a higher leaf dry matter accumulation. King \& Stark (2000) attributed this effect on the importance of water in the process of the plants photosynthesis, since in situations of water deficit the photosynthetic rate decreases due to stomatal closure. This causes a decline in gas exchange, especially of the $\mathrm{CO}_{2}$ entry into the plant and thus a reduction in the amount of carbohydrates produced. Furthermore, the decrease in water content prevents the release of electrons used for the performance of the photosystem one, which also leads to losses in dry matter accumulation (Sun et al. 2014).

Tuber fresh weight: Is showed on figure 3 the results of this parameter from week seven up to the end, 21 WAP, which is the closest moment to harvest of the research are registered. It is noted that the treatment T3 exhibits a general tendency to increase the tuber fresh weight, however, during all samplings had among the treatments at the lowest average weight. The treatment T2 shows an increase of tuber fresh weight from week 11 and its averages are higher than those of treatment T3, the check. Treatment T1 also presents an increase-starting at week 11, but it is after week 15 its greatest increase is observed and it also ends with the highest weight. From the stage of full bloom to plant maturity, water scarcity can cause the foliage to remove water from the tubers remove and, consequently, these lose weight (Rodríguez, 2010). 


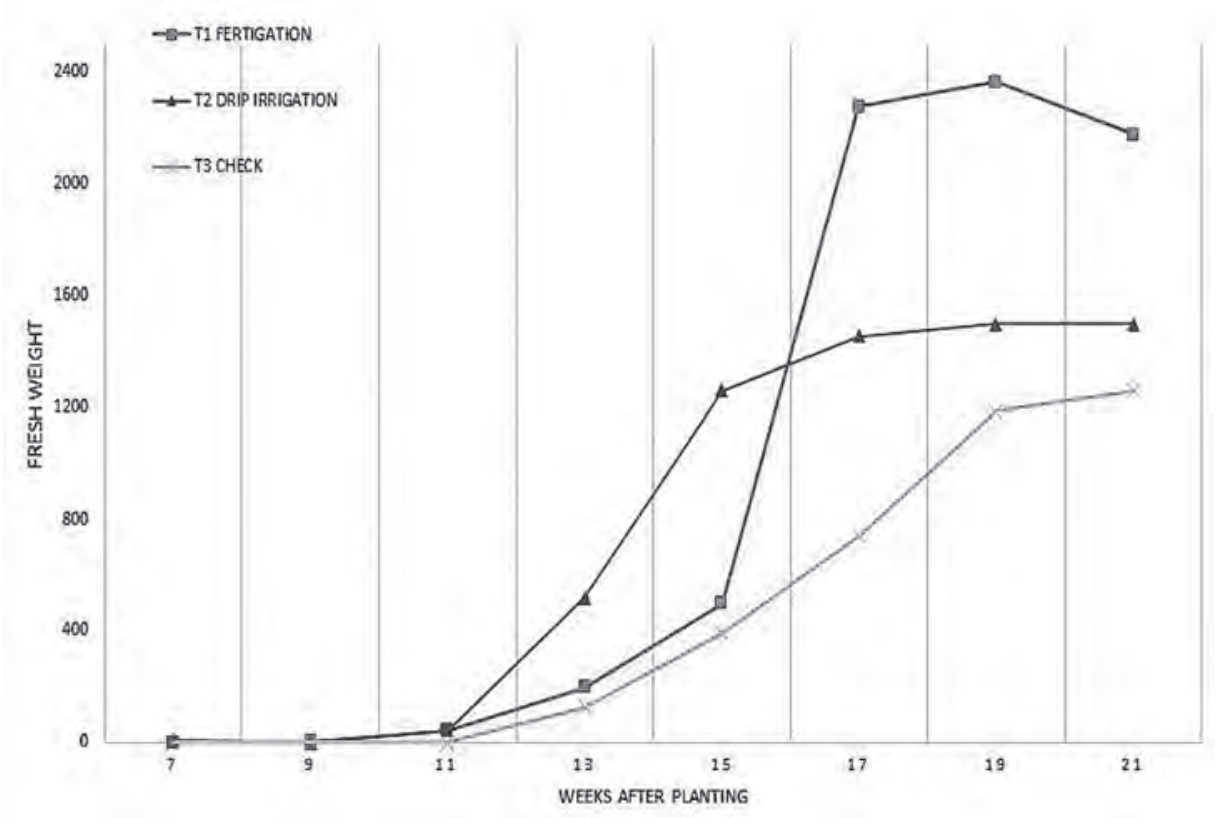

Figure 3. Mean tuber fresh weight per plant, submitted to two irrigation systems, compared with the check.

The variable tuber fresh weight corresponds to the most important parameter because it is the way the product is marketed and showed significant differences at weeks 13 , 15 and 21 . The sample of week 21 is the most relevant one, being the closest to the harvest and can be used to forecast the tuber production.

The data obtained at week 13, showed that treatment T2 had the highest tuber fresh weight, the $519 \mathrm{~g}$ is the average and established statistically significant differences with T3, with an increase of $308 \%$; T3 only reached $127 \mathrm{~g}$, being the treatment with the lowest average. The sample of T2 at week 15, with an average of $1259 \mathrm{~g}$ tuber fresh weight also presents statistical differences with the other two other treatments, with an increase of $152 \%$ and $220 \%$ compared to T1 (499 g) and T3 (393g), which showed much lower averages and are grouped together, with no significant differences between them.

Observations made at week 21 , reviled statistically significant differences between $\mathrm{T} 1$ and $\mathrm{T} 3$, showing the treatment fertigation an increase of $72 \%$ compared to the control. Treatment T2, drip irrigation, with $1488 \mathrm{~g}$ tuber weight shows an intermediate value.

According to the results obtained Vos \& Groenworld (1986), the final crop yield is directly related to the amount of biomass that it has reached at the end of the vegetative stage. Assessments realized within the diverse evaluations showed that treatment $\mathrm{T} 1$ presented on average a higher value of stem length and fresh leaves and stem matter, being this the whole plant biomass. This superiority triggered a higher photosynthetic rate, which is reflected in a larger tubers filling achieved with this treatment.

Tuber formation is considered one of the most important stages of the phenological cycle of the potato crop. In this, tubers begin to swell from stolons due to the photoasimilates produced by the leaves, this occurs between weeks 5 to 7 after planting (Rodríguez, 2010). Water stress at this stage of the crop cycle generates decreases in yield and an increase in tuber deformations (Sun et al. 2014).

King \& Stark (2000) point out that this happens because in the process of translocation of photoassimilates to the tubers, this is the moment when the highest rates transpiration rate occurs and, therefore, the plants highest water requirements arise.

It is stated that the absence of the Guatemaltecan potato tuber moth in the commercial plot, did not allow the evaluation of the effect of irrigation on the larvae damage to the tubers of the variety Diacol Capiro R12. However, one should not rule out the possible influence of this practice on the insect's population.

From this research it is concluded that the implementation of a fertigation system in the potato variety Diacol R12Capiro increases the yield by $72 \%$ compared to a crop with a 
conventional management. Only with the water applications the crop yield increases by $18 \%$ compared to the control. The water availability throughout the different plant growth stages and in favor of its water requirements affects positively the development of the determinants and components of the crop yield, resulting in increased production.

Conflicts of interest: The manuscript was prepared and revised by all authors, who declare the absence of any conflict, which can put the validity of the presented results in risk.

\section{BIBLIOGRAPHY}

1. AGUIAR NETTO, A.O.; RODRIGUES, J.D.; PINHO, S.Z. 2000. Análise de crescimento da cultura da batata submetida a diferentes lâminas de irrigação. Pesquisa Agropec. Bras. 35(5):901-907.

2. AGUILAR, M.G.; CARRILLO, J.A.; RIVERA, A.A.; GONZÁLEZ HERNÁNDEZ V.A. 2006. Análisis de crecimiento y de relaciones fuente-demanda en dos variedades de papa (Solanum tuberosum L.). Rev. Fitotec. Mex. 29(2):145-156.

3. BOSNJAK, D.; PEJIK, B. 1997. Potatoes water requirement in the Chernozem zone of Yugoslavia. Acta Horticulturae. 449(1):211-215.

4. CADAHÍA, C. 1996. El Sistema de Fertirrigación para una fertilización racional de los cultivos en sustratos y suelos. En: Rodríguez, A. (ed.). Hidroponía. Cursotaller Internacional. Universidad Agraria la Molina. Centro de Investigación de Hidroponía y Nutrición Mineral, Lima, Perú.

5. DANE. 2013. ENCUESTA NACIONAL AGROPECUARIA ENA-2012. Disponible desde Internet en: http://www. agronet.gov.co/www/htm3b/public/ENA/boletinprensa-ENA-2012.pdf (con acceso 09/02/2015).

6. DARWISH, T.M.; ATALLAH, S.; HAJHASANYA, H. 2006. Nitrogen and water use efficiency of fertigated processing potato. Agr. Water Managem. 85:95-104.

7. EKANAYAKE, I. 1994. Estudios sobre estrés por sequía y necesidades de riego en la papa. Guía de Investigación CIP 30. Lima, Perú. Centro Internacional de la Papa. 40p.

8. FAOSTAT. 2014. Potato Production quantities by country, Average 1992 - 2012. Disponible desde Internet en: http://faostat3.fao.org/faostat-gateway/go/to/ browse/Q/QC/E (con acceso 09/02/2015).
9. FEDEPAPA. 2014. Cultivo de la Papa. Disponible desde Internet en: http://www.fedepapa.com/?page $\mathrm{id}=401$ (con acceso 09/02/2015).

10. FERNÁNDEZ, S. 1996. Efecto de dos prácticas culturales sobre poblaciones de insectos plaga de tubérculos de cultivo de papa (Solanum tuberosum L.). Rev. Fac. Agron. (LUZ). 14:603-610.

11. FERREIRA, T.C.; GONCALVES, D.A. 2007. Crop-yield/ water-use production functions of potatoes (Solanum tuberosum L.) grown under differential nitrogen and irrigation treatments in a hot, dry climate. Agric. Water Manag. 90(1/2):45-55.

12. GEREMEW, E.B.; STEYN J.M.; ANNADELE, J.G. 2007. Evaluation of growth performance and dry matter partitioning of four processing potato (Solanum tuberosum) cultivars. New Zealand J. Crop Hort. Sience.35:385-391.

13. HAVERKORT, A.J.; VAN DE WAART, M.; BODLAEADER, K.B.A. 1990. The effect of early drought stress on numbers of tubers and stolons of potato in controlled and field conditions. Potato Res. 33:89-96.

14. JERÉZ, J.; SIMPFENDÖRFER, C. 2000. Efecto del riego en cultivos de papa. Tierra Adentro. Especial riego y drenaje. INIA Instituto de Investigaciones Agropecuarias. 34:36-38.

15. KING, B.; STARK, J. 2000. Potato irrigation management. University of Idaho, Coperative extension system, College of agriculture. Disponible desde Internet en: http://info.ag.uidaho.edu/resources/PDFs/BUL0789. pdf (con acceso el 26/01/2015.

16. MOTALEBIFARDA, R.; NAJAFIA, N.; OUSTANA, S.; NYSHABOURIA, M.R.; VALIZADEHB, M. 2013. The combined effects of phosphorus and zinc on evapotranspiration, leaf water potential, water use efficiency and tuber attributes of potato under water deficit conditions. Scientia Horticulturae 162:31-38.

17. ÑÚSTEZ, C.E.; SANTOS, M.; NAVIA, S.; COTES, J.M. 2006. Evaluación de la fertilización fosfórica foliar y edáfica sobre el rendimiento de la variedad de papa 'Diacol Capiro' (Solanum tuberosum L.). Agr. Col. 24(1):111-121.

18. ÑÚSTEZ, C.E.; SANTOS, M.; SEGURA, M. 2009. Acumulación y distribución de materia seca de cuatro variedades de papa (Solanum tuberosum L.) 
en Zipaquirá, Cundinamarca (Colombia). Rev. Fac. Nal. Agr. Medellín. 62(1):4823-4834.

19. PACHECO SAGUÍ, J.; PÉREZ CORREA, A. 2010. Evaluación del riego de la papa en la Empresa de Cultivos Varios "Valle del Yabú", Santa Clara, Cuba. Rev. Cienc. Tecn. Agropec. 19(3):47-52.

20. RAMOS DE SOLÓZANO, G.; LACRUZ ROJAS, C.; GARCÍA DE FLORES, A.; BECERRA M., F. 1995. Efecto de la humedad sobre el cultivo de la papa y la incidencia de plagas a nivel de tubérculos, en Bailadores, Estado Mérida. Rev. Fac. Agron. (LUZ). 12:133-144.

21. RODRÍGUEZ, L. 2010. Ecofisiologia del Cultivo de la papa (Solanum tuberosum L.). Rev. Col. Cienc. Hort. 4(1):97-108.

22. SANTOS, M.; SEGURA, M.; ÑÚSTEZ, C.E. 2010. Análisis de crecimiento y relación fuente-demanda de cuatro variedades de papa (Solanum tuberosum L.) en el municipio de Zipaquirá (Cundinamarca, Colombia). Rev. Fac. Nal. Agr. Medellín. 63(1):5253-5266.

23. SERMET, O.; CALISKAN, H.M.; CALISKA, O. 2005. Different irrigation methods and water stress effects on potato yield and yield components. Agric. Water Manage. 73:73-86.

24. SOLANO S., J.; MEDINA M., L.; NISSEN M., J. 2003. Efecto de niveles y frecuencias de riego por aspersión en papa (Solanum tuberosum L.). Agrosur. 31(2):4759.
25. SUN, Y.; YAN, F.; CUI, X.; LIU, F. 2014. Plasticity in stomatal size and density of potato leaves under different irrigation and phosphorus regimes. J. Plant Physiol. 171:1248-1255.

26. TABARES, E.; JARAMILLO, S.; GONZÁLEZ, L.; COTES, J.M. 2009. Respuesta de la papa (Solanum tuberosum L.) variedad Diacol Capiro a la fertilización en un andisol del Oriente Antioqueño. Rev. Fac. Nacional de Agronomía, Medellín 62(2):5099-5110.

27. TORRES W., F. 1997. Biología y Manejo Integrado de la Polilla Centroamericana de la Papa Tecia solanivora en Venezuela. Maracay, Ven.; Fondo nacional de Investigaciones Agropecuarias/Fundación para el desarrollo de la Ciencia y la tecnología del estado de Táchira (Serie A-No. 14). 60p.

28. TOURNEUX, CH.; DEVAUX, A.; CAMACHO, M.R.; MAMANI, P.; LEDENT, J.F. 2003a. Effects of water shortage on six potato genotypes in the highlands of Bolivia (II): water relations, physiological parameters. Agronomie. 23:180-190.

29. TOURNEUX, CH.; DEVAUX, A.; CAMACHO, M.R.; MAMANI, P.; LEDENT, J.F. 2003b. Effects of water shortage on six potato genotypes in the highlands of Bolivia (I): morphological parameters, growth and yield. Agronomie. 23:169-179.

30. VOS, J.; GROENWOLD, J. 1986. Root growth of potato crops on a marine-clay soil. Plant Soil. 94:17-33.

Recibido: Julio 3 de 2015

Aceptado: Octubre 16 de 2015

How to cite (Cómo citar):

Peña Baracaldo, F.J.; Zenner de Polanía, I. 2015. Irrigation response of potato (Solanum tuberosum L.) Var. R12 Diacol Capiro. Rev. U.D.C.A Act. \& Div. Cient. 18(2): 385-392. 